\title{
Review
}

\section{Technosystem: The social life of reason}

\author{
Andrew Feenberg \\ Harvard University Press, Cambridge MA, 2017, xiii+233 pp., \\ ISBN: 978-0674971783
}

Contemporary Political Theory (2019) 18, S102-S105. https://doi.org/10.1057/s41296017-0184-1; published online 21 December 2017

Observing what I was reading, a colleague noted that the pre-colonic Technosystem, and the post-colonic - The Social Life of Reason - of Andrew Feenberg's recent book 'don't seem to belong together' and, on the surface, that may appear true. The hard-edged, monolithic rationalism of a word like 'technosystem' appears to contradict the very notion of a social life. I admit to initially sharing my colleague's confusion as to the relation. However, as Feenberg unpacks his ideas over seven concise chapters, a single, globe-spanning system of technical functionality is actually the best location for tracing the social construction, circulation, and re-articulation of rationality.

Feenberg defines 'technosystem' as 'a field of technical practices aimed at control of the environment, whether natural, economic, or administrative' (p. 159). Modernity is a program to universalize these practices and, at present, this project is complete. The ubiquity of reason - all social institutions are shot through with the logic of scientific reason - necessitates a change in the function of critique. As he observes earlier in the book, the function of critique can no longer be one of 'establishing the boundaries' between the technosystem and the social life world because 'instrumental and communicative rationality interpenetrate in all institutional settings' (p. 44). Instead, he argues that the ubiquity of the technosystem renders transparent the seemingly irrational factors (interests, biases, etc.) that have always been secretly integral to the reification of technical objects. Critique must now map and examine the sites of conflict between lived experience and scientific rationality that, for Feenberg, are possible vectors for remapping the state of reason.

This account starts a bit slowly, with an introduction that, upon finishing the book, is clearly setting up the terrain for the later insights but which was a bit disorienting upon first contact. Similarly, the first chapter, which articulates the new way we read Karl Marx now - following and through Michel Foucault's theories - is very interesting, especially for readers of either figure, but does not contribute to a sense of what the book was about or how it related to the larger questions of technology and politics that Feenberg is concerned with. However, the

(c) 2017 Macmillan Publishers Ltd., part of Springer Nature. 1470-8914 Contemporary Political Theory Vol. 18, S2, S102-S105 www.palgrave.com/journals 
introduction and first chapter are worth working through: the next chapter is where the methods, topics, and approaches that structure the rest of the book begin to become apparent and the early pieces of the argument begin to click together.

Here Feenberg lays out what he calls 'critical constructivism,' the method that informs the book. In this approach to social thought, Feenberg combines the critical faculties of Frankfurt School critical theory - especially their work developing Georg Lukács's argument that individuals use 'the laws of social life ... as the basis of technical manipulations' (p. 41) - with the insights into the social nature of reason provided by constructivist science and technology studies (STS) methodologies, which Feenberg considers to include both social constructivism and actornetwork theory. Feenberg is interested in this concatenation for the granular insights into the circulation of reason that social constructivist methods can reveal. However, as he argues, these methods are also insistent on the symmetry between all actors in a particular network. Thus, as Feenberg reads through a particularly good accounting of Bruno Latour (pp. 48-54), constructivist methods are blind to power: all actors are equal in these accounts and therefore they cannot account for power asymmetries between them (say a massive, multinational corporation that is dumping waste in drinking water and the residents thus affected by this waste dumping). By combining Frankfurt School critical theory - and its important account of reification and dereification - with these STS methods, Feenberg articulates a new form of political analysis, which both accounts for the social struggles that shape reason and the tales of power these struggles tell.

This methodological insight structures the whole book. The remaining chapter in the 'Method' section, which discusses the relationship between Gilbert Simondon and Herbert Marcuse, merely adds further nuance to the central insight in chapter 2. However, this account left me with some nagging questions. Particularly, I find it puzzling that Feenberg more or less ignores the insights of feminist STS scholarship. Donna Haraway, whose classic essay 'Situated Knowledges' (Haraway 1990) essentially articulates Feenberg's point by referring to a different set of theorists, receives a single mention, and only then in a passing reference to her work on the cyborg. Similarly, a variety of works by feminist scholars in STS are confined to a single footnote, despite the fact that, in addition to Haraway, figures such as Susan Leigh Star and Karen Barad have written extensively about the question of reason and its social circulation within infrastructural space.

The question of infrastructure raises a further problem with Feenberg's book: there are very few examples, which is odd given that this book purports to show how lived experience confronts scientific reason in the lifeworld of technical artifacts. Despite frequently mentioning the environmental movement as one (of the two) example(s) of this sort of work, there are no major examples of environmental actions in the book, beyond a few hypothetical activist actions. Further, chapter 4, which attempts to apply critical constructivism to the Internet, suffers from some conceptual shortcomings.

(c) 2017 Macmillan Publishers Ltd., part of Springer Nature. 1470-8914 Contemporary Political Theory Vol. 18, S2, S102-S105 S103 
In that chapter, which constitutes the 'Application' section of the book, Feenberg offers criticism of works by Christian Fuchs and Jodi Dean, who both offer Marxist critiques of the internet as increasingly a space dominated by corporate capitalism. In contrast, Feenberg insists that the internet is a space of competition between two models: one that views it as a platform for facilitating community interactions and another that conceives it as a space of media consumption, more akin to television than to a street corner (p. 101). He concludes this section by suggesting that 'the Internet is not yet completely dominated by business. There is still a free space for community in cyberspace' (p. 107). Many of his examples of this community model - Occupy Wall Street and the Arab Spring, as well as the elections of Barack Obama and Donald Trump - rely on the fact that 'Facebook and Twitter supplemented more traditional means of discussion and mobilization' (p. 107). Facebook and Twitter are both publicly traded companies that appear to enable democratic debate as a means of value extraction. At the level of infrastructure, the internet has become very corporate. While it may have begun with a democratic bent, as Feenberg argues later in the book, 'design is never fixed once and for all ... new actors can open the "black box" and resignify the object' (p. 153). Thus, the internet could shift to a corporate model through this process of resignification.

After Chapter 4, the remaining three chapters, which make up the 'Theory' section, are built on Lukács, Marcuse, and Martin Heidegger to complete the unfinished task of earlier generations of Frankfurt School thought: imagining a new alternative to instrumental rationality. Chapter 5 uses the idea of a 'Gestalt switch' as a basis for the confrontation between lived experience and scientific rationality as the key political struggle at present. Chapter 6 provides an overview of and intervention into the various means of determining and fixing an object's function, concluding that function 'is a social process in which the technical mentality meets cultural or political desiderata and constraints in the design of concrete artifacts or systems' (p. 160). Chapter 7 argues for the role of judgement as the logic of underscoring public intervention into the technosystem and posits rhetoric as a key practical adjunct to this process, though, as a professor of rhetoric, I would have liked to see the relevant work on judgement in rhetorical theory (for instance, Chaïm Perelman and Lucie Olbrechts-Tyteca's The New Rhetoric (Perelman and Olbrechts-Tyteca 1991 [1958]) or Kenneth Burke's The Rhetoric of Motives (Burke 1950)) cited, in addition to a glance at Aristotle.

Overall, the interventions Feenberg makes in Technosystem are insightful. He is an inspired and inspiring reader of the Frankfurt School. Additionally, I applaud his attempts to open up that often hermetically sealed citational universe to other voices. Moreover, I think the idea of critical constructivism has much to offer, as I found here a vocabulary for articulating my own frustrations with the often passive model of power deployed in many constructivist accounts. However, the book has some citational gaps, particularly regarding feminist STS work, and the application section falls a bit flat.

S104 (c) 2017 Macmillan Publishers Ltd., part of Springer Nature. 1470-8914 Contemporary Political Theory Vol. 18, S2, S102-S105 
That said, in 2017, at a moment where net neutrality is once again under assault in the United States, where the supposed rationality of algorithmic advertising practices are the subject of Congressional hearings, and where reactionary voices daily leverage the gap between reason and lived experience to normalize extremism online, the ability to account for the circulation and construction of rationality as a basis for power with the granularity of constructivist analysis is an important methodological development. Thus Feenberg establishes that a universalized technosystem offers the opportunity to visualize and trace the social construction of reason. He offers much to think about and work with in Technosystem.

\section{References}

Burke, K. (1950) A Rhetoric of Motives. Berkeley, CA: University of California Press.

Haraway, D. (1990) Situated knowledges: The science question in feminism and the privilege of partial perspective. In: D. Haraway (ed.) Simians, Cyborgs, and Women: The Reinvention of Nature. New York: Routledge, pp. 183-202.

Perelman, C. and Olbrechts-Tyteca, L. (1991 [1958]) The New Rhetoric: A Treatise on Argumentation. Translated by J. Wilkinson and P. Weaver. South Bend, IN: University of Notre Dame Press.

Andrew Pilsch

Texas A\&M University, College Station, TX 77843, USA apilsch@tamu.edu 